\title{
Territorial invasion
}

\section{or symbiotic relationship?}

\section{Technical services and reference cooperation}

\author{
by Naomi R. Sutherland and Valarie P. Adams*
}

$\mathrm{H}$ ave you heard of the 5,000-year war? You know, the one that supposedly still exists between catalogers and reference librarians? During the 1990s, Will Manley satirized "reference librarians [who] love to refer to catalogers as 'socially dysfunctional nitpickers"' and catalogers who find "Imprecise, Impractical, and Illogical" a logical subject heading for their professional neighbors. ${ }^{1}$

These phrases, though perhaps rarely thought and never spoken, do spotlight the occasional differences of opinion that exist between reference and cataloging regarding departmental communication and local practice. Issues may include questions about where materials should be placed in the collection, the extensiveness of holdings notes viewed by the OPAC end-users, and the use of certain MARC fields.

The course of resolving such issues may support Manley's interpretation. Conversely, this process may demonstrate the mutual interdependence of technical services and reference. This relationship persists as a durable topic at library conferences and in numerous articles dating to the early 1900s. Many of these articles feature the card cata$\log$, followed in time by the online catalog, as a centerpiece of cooperation. ${ }^{2}$

Noting these realities, we decided to informally survey catalogers regarding the present state of communication and cooperation between technical services and reference.

\section{AUTOCAT Survey}

We posed the following set of questions on AUTOCAT, the cataloging electronic discussion list, in June 2002:

Will you all please share with me how you as catalogers communicate with your reference departments; also, how do they communicate with you? Do they just tell you about concerns they have (i.e., about your catalog) individually or do you have something formal set up? What about when you have something to tell them? What are some of the concerns that are discussed between the two departments?

We received 26 responses with comments: 18 from academic libraries, 7 from public libraries, and 1 from a special interest library. Positive responses comprised the majority; only one person reported a dreadful situation that lent credibility to Manley's wry observations. The size of the library often determined the type of response: the larger libraries use more formal communication. Some libraries use committees while others have their work areas situated close enough

\section{About the authors}

Naomi R. Sutherland is reference/instruction librarian, e-mail: Naomi-Sutherland@utc.edu, and Valarie P. Adams is head, cataloging and bibliographic records at the University of Tennessee-Chattanooga, e-mail:Valarie-Adams@utc.edu *The authors would like to thank Tyson $R$. Land for his editorial assistance. 
to invite cross-cubicle communication.

Eight broad categories of communication emerged from the responses: formal meetings, policy committees, forms (electronic and paper), newsletters, e-mail, casual conversations, liaison assignments, and catalogers serving at the reference desk.

\section{Symbiotic relationship?}

"Frequent, cordial interaction is the key," observed a cataloger responding to our AUTOCAT survey. As with all symbiotic relationships, such contact enhances the effectiveness of both groups. Situations can degenerate quickly when people in the work place lack this type of communication. One survey testimonial included references to routinely ignored instructional memos, snide comments, or "ultra-humble begging notes that evince terror of our response" coupled with a belief that "public staff seems convinced we exist to obstruct their best efforts."

Who initiates the interaction? The survey responses indicate that reference often opens the conversations over matters of common interest, e.g., the online catalog. The replies also reveal a significant amount of informal two-way communication. Partly due to work area proximity, this casual contact transpires most often in smaller libraries. As one librarian asked, "Are you close enough together in the building that you have your coffee together in the morning?"

Medium-sized and large libraries and those separated by geographical distance often rely on formal meetings for effective communication. For instance, one cataloger reported:

I attend nearly all of the reference team meetings so I hear their concerns there. ... We also have a reference representative attend our biweekly meeting of the technical services teams. These steps have led to a great working relationship between the cataloging team and the reference team.

Other formal means of communication include policy committees, task forces, and electronic and print forms. Examples of issues addressed through such avenues are local cataloging practices and priorities, policy clarification, and collection relocation.
Staff may report record errors and can request reclassification of an item or additional subject headings. One library system's form is named "Catalog Watch."

In addition, liaison assignments use both formal and informal communication methods. Their existence showcases, theoretically and practically, the complementary nature of the reference and cataloging roles. Liaisons communicate needs and wishes between library departments, such as rush-processing requests for items in demand or scheduling reference weeding projects so as not to overburden cataloging at inopportune moments.

Perhaps the most practical form of communication occurs when reference and cataloging librarians trade places weekly, monthly, or quarterly. This arrangement fosters the common good by increasing empathy, enhancing firsthand understanding, and assuaging a vague curiosity about "how the other half lives." The AUTOCAT survey spotlighted the fact that while catalogers frequently serve at the reference desk, reference librarians rarely engage in cataloging processes.

\section{Ruins of war: Unsuccessful communication techniques}

Despite some indications to the contrary, no group of librarians is perfect. What can you do if the ground between your cataloging and reference departments reminds you of the dimiltarised zone, never mind a battle scene from the so-called 5,000-year war?

Problematic situations may include a lack of support from managers in the event of an interdepartmental communication failure or an absence of individual good will and approachability. Defensiveness, feeling the need to constantly justify one's actions, may also rear its ugly head. This communication filter stops the free exchange of ideas and concerns because self-protection commands centerstage.

What has happened to reciprocal altruism? What has happened to focusing not only on keeping a listening ear but also an open mind to the other person's request? The library exists as a community of common interests united by the goal of providing excellent service to the user and affording access to materials. Or does it? 
One example of a communications breakdown occurs when reference librarians find themselves too busy to notify catalogers of problems in the catalog. Or, if they do send a quick e-mail or write a note on a catalog printout, it may be vague in describing the difficulty or the suggestion for improvement. How can this be remedied?

Often, librarians record some of the words that a patron uses when asking questions at the reference desk. These words can possibly be used to provide additional online catalog cross-references.

Librarians might also take the time to ask their questions in person. Face-to-face communication provides an opportunity to talk informally and to become acquainted with the other person while gathering solutions to problems. A casual chat may even present ideas for how to help that person in the future or to explore how they might assist you. Seeking out individuals can be awkward and could mean repeated tries to have your ideas heard, but keep trying. With this modus operandi in mind, the key lies in regular communication and in interaction with colleagues in a variety of settings.

\section{Rewards of cooperation}

Discussions focusing on mutual respect and appreciation for the skills of catalogers and reference librarians are not new to the corpus of library literature. In 1951, Clara Ann Kuhlman, then business and social science librarian at the University of Texas-Austin, wrote an article spotlighting the basic principles of cooperation. She suggested that uniform cataloging rules while important be applied in such a way as to promote flexibility and greater service to the reader and to those assisting him or her in locating materials. She commented that it is not a "healthy situation" for catalogers to decide the majority of rules without input from others, including those who directly assist the readers.

Kuhlman also addressed the reference librarians, urging them to "realize that it is their duty to inform the catalogers of the uses which the reader tends to make of the catalog and the ways in which the catalog meets or fails to meet the needs of the reader." 3

More than 52 years later, collaboration thrives at the University of Tennessee-
Chattanooga's Lupton Library as librarians from reference, cataloging, and audiovisual resources continue heeding Kuhlman's advice. Representatives from each of these departments recently used their complementary functions by planning and presenting a successful seminar to more than 75 students and faculty of the university's music department. This seminar featured detailed demonstrations of how to search the online catalog for musicspecific materials, including vocal performance scores and various types of sound recordings. Also included were a brief presentation on advanced searching capabilities for Music Index and navigating ILLIAD for use in requesting interlibrary loan materials.

Preparation for the music seminar gave librarians from each area the opportunity to ask questions of each other, observe and perform sample searches, and have the results explained from a technical perspective. Our informal study reminded us that people from different departments approach the same search with outlooks formed according to their relationship to and understanding of the catalog.

Our audiovisual librarian contributed her knowledge of music. The reference and instruction librarian focused on how to present clearly the information to the students and faculty. Our cataloger added her in-depth knowledge of cataloging rules, particularly those of authority, in order to help us better understand and later explain music-specific search strategies to the audience. Each perspective enhanced our success and emphasized how our joint efforts contributed to the satisfaction of our users. Seminar planning and the presentation gave us opportunities to appreciate our own and others' roles in providing services to our users, services which no single individual could accomplish unaided.

\section{Future directions}

Each librarian at Lupton Library, regardless of department, staffs the reference desk two or more Saturdays each year. 'Therefore, particular importance lies in our staying current on database and catalog usage. We plan to provide short in-house seminars reciprocally. One month a reference librarian will be responsible for a 30-minute presentation and discussion of a particular database. The next 
month the head of cataloging will present a brief seminar on demystifying serials holdings. These sessions will occur at a consistent time and day of the month in order to facilitate scheduling and planning. This interdepartmental interaction will also allow opportunities to suggest future seminar topics and to discuss innovative ways to provide even better service to our users.

Ongoing nurturing of interdepartmental cooperation and understanding enhances the stability and productivity of symbiotic relationships. Rumors of war and territorial tensions diminish when people actively work together to understand and support each other.

\section{("Librarians ... " continued from page 10)}

sessments both hard and "soft"-about the value of their partnerships. Front line librarians work with their library administrations to share those stories upwards and outwards. In return, the institutions and communities supported by these partnerships reciprocate the support, even through difficult economic times.

Library directors and front-line librarians need to forge their own strategic partnership, if libraries are to truly respond effectively to the challenge of becoming more relevant and making that relevancy better recognized outside of the library's virtual or physical walls. Together, management and front-line library staff need to identify and select those partnerships through which the library can make a real contribution to student and faculty knowledge building through concrete achievements.

Our goal as librarians should be to nourish these partnerships, make certain that the outcomes are valuable to the community, and, most importantly, ensure that this value is clearly and broadly communicated. In this way, academic libraries will be better positioned to meet some of our most pressing challenges, such as declining budgets and charges of irrelevancy, because we will be active and essential partners in the core work of our academic communities--teaching, learning, and research.

\section{Notes}

1. Sharon Elteto and Donald G. Frank, "The Politics of Survival in the Postmodern Library," Portal: Libraries and the Academy 3, no. 3 (July 2003): 495.

\section{Notes}

1. Will Manley, The Truth About Reference Librarians. (Jefferson, NC: McFarland \& Co., 1996), 8.

2. Ruby E. Miller and Barbara J. Ford, "Information/Reference: A Relationship Between Cataloging and Reference," Texas Library Journal 66 (Summer 1990): 48-51.

Elaine K. Rast, "Narrowing the Gap: Serials Service Improved by Cooperation Between Technical and Public Services," The Reference Librarian 27-28 (1989): 105-122.

3. Clara Ann Kuhlman, "How Catalogers Can Help the Reference Librarian," Wilson Library Bulletin 26 (November 1951): $267-$ 269.

2. See Tyrone H. Cannon's president's page on the ACRL Web site. Www.ala.org/acrl, click on "President's Page" (accessed December 4, 2003).

3. Concept taken from Michael Levine "Selling Goodness: The Guerilla P.R. guide to Promoting your Charity, Non-Profit Organization, or Fundraising Event" (Los Angeles: Renaissance Books, 1998).

4. Louise Addis, "A Brief and Biased History of Preprint and Database Activities at the SLAC Library, 1962-1994" (Menlo Park: Stanford University, 2002). Www.slac. stanford.edu/spires/papers/history.html, (accessed December 5, 2003).

5. Vannevar Bush, "As We May Think," Atlantic Montbly, July 1945. www. theatlantic.com/unbound/flashbks/computer/ bushf.htm (accessed December 5, 2003).

6. Tim Berners-Lee, Weaving the Web: The Original Design and Ultimate Destiny of the World Wide Web by its Inventor (New York: Harper, 1999), 46.

7. The arXiv.org e-print archive offers automated e-prints in the areas of nlin, math, cs, qbio, and physics.

8. Referred to as HEPI, this was the "Readers' Guide" of particle physics until DESY ceased publication in 1994, redirecting all their print index effort to the online literature database, SPIRES-HEP. www.slac. stanford.edu/spires/hep/.

9. Travis Brooks and Michael Peskin, ToP Cited HEP Articles from SPIRES-HEP Database, SLAC Library (Menlo Park: Stanford University, 2002). wwww.slac.stanford.edu/library/ topcites/ (accessed December 5, 2003). 